$\underline{\text { Review Article }}$

\title{
HUNTINGTON'S DISEASE: CURRENT ADVANCES AND FUTURE PROSPECTS
}

\author{
BRIGHT LEMUEL JOHN N* ${ }^{*}$ AKILA RAMANATHAN² \\ ${ }^{1}$ College of Pharmacy, Madras Medical College, Chennai, Tamil Nadu, India, ${ }^{2}$ Department of Pharmaceutical Biotechnology, College of \\ Pharmacy, Sri Ramakrishna Institute of Paramedical Sciences, Coimbatore, Tamil Nadu, India \\ Email: brightlemu@gmail.com
}

Received: 25 Aug 2021, Revised and Accepted: 07 Oct 2021

\begin{abstract}
Huntington's disease is a neurodegenerative disease which is caused by dominantly inherited cytosine-adenine-guanine trinucleotide repeat expansion in the huntingtin gene of chromosome 4. Present survey reveals 2.7 per 100000 people are affected by huntington's disease worldwide. The symptoms present with these patients are progressive motor, cognitive and psychiatric disorders. The early symptoms are chorea and loss of balance. This review aims to observe the present data available concerning huntington's disease, symptoms, age of onset, risk factors, benefits of early diagnosis and genetic attribution. There is no cure for the disease. The article searched, selected and reviewed were from google scholar, medscape, NIH MedlinePlus, PubMed database using MeSH terms huntington's disease, recent therapeutic advancement from 2003 to July 2021 with no language restriction and additional studies were included from the reference lists of relevant articles. The present review provides clinical features, diagnosis, symptomatic management and ongoing research. Hence this review will have an impact to create awareness for the society and researchers to find future treatment for Huntington's disease.
\end{abstract}

Keywords: Huntington's disease, Symptom, Gene, Treatment

(C) 2021 The Authors. Published by Innovare Academic Sciences Pvt Ltd. This is an open access article under the CC BY license (https://creativecommons.org/licenses/by/4.0/] DOI: https://dx.doi.org/10.22159/ijpps.2021v13i12.42979. Journal homepage: https://innovareacademics.in/journals/index.php/ijpps.

\section{INTRODUCTION}

Huntington disease (HD) is a highly defective neurodegenerative disease which includes symptoms like progressive motor, cognitive and psychiatric disorders. It occurs by the repetition of cytosine, adenine and guanine (CAG) trinucleotide on the chromosome $4 \mathrm{p} 16.3$ in the huntingtin gene [1]. This huntingtin gene gets translated into a mutant huntingtin protein (mHTT) [2]. In HD the symptoms are analogous to several other diseases. The family history plays a major role in HD patients, though there are $1-3 \%$ patients that have no family history [3]. There is a $50 \%$ chance of inheriting the huntingtin gene from parents to children. Inheriting the gene develops the disease [4,5]. HD can be classified into Adult onset huntington's disease and Juvenile Huntington's disease (JHD). Adults in the long run develop the symptoms in their mid 30s and 50s whereas symptoms of JHD are alike to Parkinson's disease which constitute about $5 \%$ of HD cases [6]. The learning difficulties at school are the first sign and the majorities have epileptic fits. In HD 75\% of father plays a major role in transmitting the disease to their children [7]. Nearly 2.7 per 100000 people are affected by HD worldwide. The patients with more CAG repeats exhibit this disease. This review is to find the aetiology, pathophysiology, types of diagnostic tests, clinical classification, management and ongoing research for management of HD $[8,9]$.

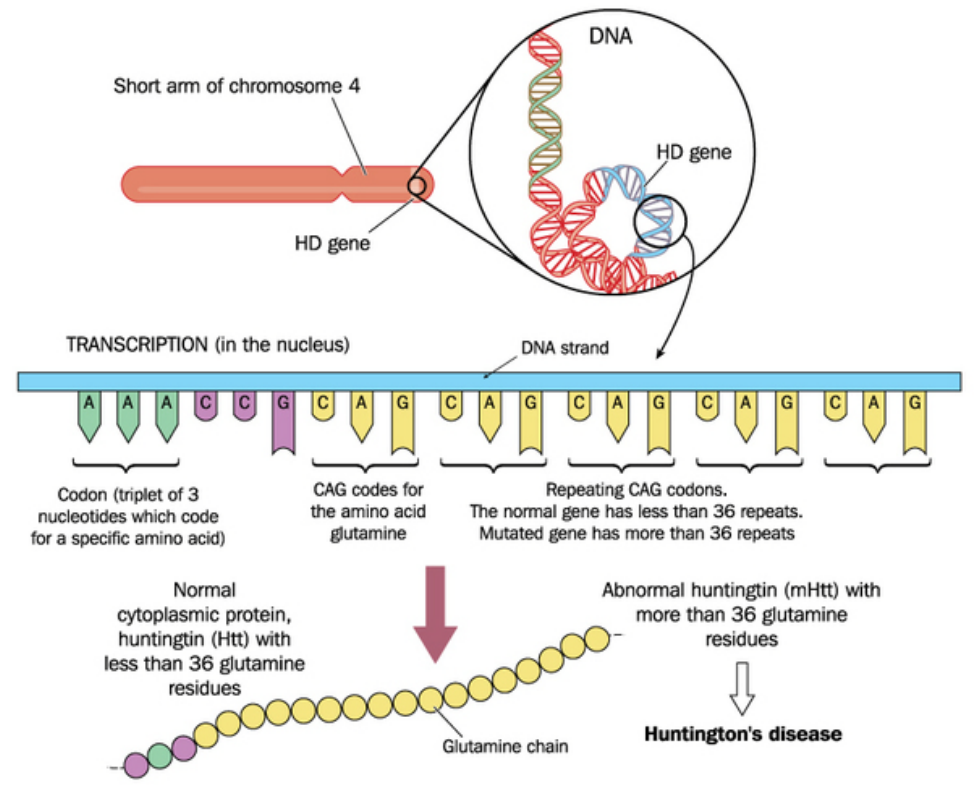

Fig. 1: Schematic demonstration of gene mutation causing Huntington's disease [10]. 1. Cytosine, adenine, and guanine (CAG) trinucleotide repeats on the short arm of chromosome 4p16.3 in the Huntingtin (HTT) gene having less than 36 repeats. 2. Expansion of unstable trinucleotide repeats 36 and above on HTT gene causes huntington's disease 


\section{Aetiology and pathophysiology}

HD is mainly caused by elongation of CAG repeats of chromosome 4 p16.3 in the huntingtin gene. Patients affected with HD can be identified by genetic testing because HD is linked with the number of CAG repeats [11]. Patients with 36 repeats or more are affected by this disease. Whereas in JHD the CAG repeats are more than 55 predominantly. The length of CAG from 29 to 35 does not cause the disease but it can lengthen in the generations. The male parent is the major cause for inheriting the disease [9].

The majority of signal in HD occurs within the neostriatum. The degrees of atrophy depends upon pathological grade in various regions such as basal ganglia, frontal cerebral cortex, globus pallidus, thalamus, subthalamic nucleus, substantia nigra, and cerebellum [12]. In mouse model the pathophysiology was studied and it was observed that in early HD there is an increase in inhibitory input with a little change in excitatory input to pyramidal neurons but in late HD there is a marked decrease in inhibitory inputs to pyramidal neurons and a concomitant increase in excitation. In early HD the dopamine inputs to direct medium spiny neurons increase both excitatory and inhibitory inputs via a presynaptic effect. But there is a decrease in indirect receptor function on indirect pathway medium spiny neurons, but no net presynaptic change. An increase in evoked excitatory post-synaptic currents occurs that is probably mediated post synaptically. In late HD there is a decrease in excitation to both direct and indirect medium sized-spiny neurons which is probably due to a disconnection from excitatory synaptic inputs. There also is an increase in inhibitory input, but only to indirect medium sizedspiny neurons [9].

\section{Age of onset}

There are 2 types of onsets. The early onset occurs between the age of 20 to $30 \mathrm{y}$ whereas the late onset is between 30 to $50 \mathrm{y}$. The length of the CAG repeat in the late onset is 40 to 49 whereas in early onset the repeat is more than 50 . The JHD occurs at the age below 21 and it constitutes about $5 \%$ of the cases $[13,14]$. The lifetime of the Huntington's disease is $15-20 \mathrm{y}$, it also varies depending upon the care [1]. The shortening of the telomeres leads to several neurodegenerative diseases. HD leukocytes have the shortest telomeres, among all the neurodegenerative diseases [2]. The following table 1 represents the presence or absence of HD.

Table 1: Presence or absence of HD depending on CAG repeats

\begin{tabular}{llll}
\hline CAG repeats (length) & Type & Presence/absence & References \\
\hline$>60$ & Juvenile & Presence of HD & {$[1,5,7]$} \\
Above 39 & Adult onset & Presence of HD & {$[1,5,7]$} \\
$36-39$ & Late onset (adult) & Are susceptible to HD & {$[1,5,7]$} \\
$10-26$ & - & Absence & {$[1,5,7]$} \\
\hline
\end{tabular}

\section{Symptoms}

Table 2: Types of symptoms and indications

\begin{tabular}{lll}
\hline Types & Indications & References \\
\hline Motor symptoms & Chorea, dystonia, loss of postural reflexes, bradykinesia and rigidity \\
Cognitive symptoms & $\begin{array}{l}\text { Disorganization as a result of difficulties with planning, initiating, and organizing thoughts, activities, and } \\
\text { communication; perseveration; impulsivity; perceptual distortions; lack of insight; distractibility; }\end{array}$ \\
& $\begin{array}{l}\text { difficulty in learning new information } \\
\text { [15] }\end{array}$ \\
Psychiatric symptoms & $\begin{array}{l}\text { Depression, obsessive-compulsive disorders, anxiety, irritability, apathy, hypersexuality (uncommon), } \\
\text { psychosis (uncommon) }\end{array}$ \\
Metabolic symptoms & $\begin{array}{l}\text { Weight loss and sleep disturbance } \\
\text { Dysphasia (combination of motor and language difficulties), dysphagia (combination of motor problems, } \\
\text { impulsivity, and distractibility) }\end{array}$
\end{tabular}

\section{Diagnosis}

The motor symptoms that occur in HD can be diagnosed by the total motor score (TMS) of unified HD rating scale, though TMS does not depict the precise changes when group of people with HD are analyzed. The quantitative motor tests are more accurate [19].

\section{Types of diagnostic tests}

Generally, three types of diagnostic testing are used to manifest the HD.

Type I: By collecting patient history and neurological examination. For this a neurologist will conduct a detailed interview to obtain a pedigree to rule out other conditions. And he will do physical examination such as review reflexes, balance, movement, muscle tone, hearing, walking, and mental status. After analysing type I the individual may be referred to specialists such as psychiatrists, genetic counsellors, clinical neuropsychologists, or speech pathologists for specialized management and/or diagnostic clarification $[1,4]$.

Type II: Diagnostic imaging is normally conducted if a person's family history and genetic testing are inconclusive. In this condition the physician may recommend brain imaging, such as computed tomography or magnetic resonance imaging. As the disease progresses, these scans typically reveal shrinkage in parts of the brain and enlargement of fluid-filled cavities within the brain called ventricles. These changes do not necessarily indicate HD, because they can occur in other disorders $[1,4]$.
Type III: Genetic tests. Genetic testing can confirm to determine a person's chance of developing or passing on a genetic disorder. Genetic testing makes it possible to predict with a higher degree of certainty if someone will develop HD. The most accurate and effective technique for diagnosis HD is direct genetic test which counts the number of CAG repeats in the HD gene, using DNA taken from a blood sample. The presence of 36 or more repeats supports a diagnosis of HD. A test result of 26 or fewer repeats rules out HD. The prenatal exclusion testing requires a sample of DNA from a parent or relative to identify marker HD gene and to determine if a fetus has inherited a chromosome 4 mutation from an affected grandparent. This method is used for prenatal testing $[1,4]$.

Patients at risk of HD often test before making decisions about marriage or starting their career. The emotions cannot be determined and can lead to some adverse reactions. In some cases, the patient who is in a serious relationship and is about to marry will have to learn what to tell the mate about his/her genetic disorder. For these young people this seems to end their career and it leads to a disappointment [20].

\section{Quality of life}

HD has an intense effect on the quality of life. The onset of symptoms starts with the loss of employment in the early stages of HD. The patient will need a $24 \mathrm{~h}$ care and support at the final stages [20]. Physical fitness is necessary and regular exercise can improve the quality of life [21]. Patients with HD at the early stages are not aware 
of the choreiform movements, it affects while doing the daily functioning activities. In recent studies the gait impairments, bradykinesia, and choreiform movements are the important health issues that damage the quality of life of patients. The doctors help in consulting the patients and giving them treatment when chorea interferes with the daily activities. The dopamine depleting drugs, or antipsychotics drugs are given to the patient to treat chorea [22].

\section{Management guidelines}

To manage symptoms and improve quality of life treatments are needed. Unfortunately, there is no drug available to cure HD. But both drug based and non-drug based treatments are practiced to slow down the disease progression. Drugs commonly used for symptomatic management are olanzapine, risperidone, quetiapine, clozapine, and aripiprazole for psychosis [23]. For depression, anxiety, obsessive-compulsive symptoms, irritability, aggression drugs like citalopram, fluoxetine, paroxetine, mirtazapine and venlafaxine are prescribed. Zopiclone and zolpidem are given for altered sleep-wake cycle [24]. Anticonvulsants like sodium valproate, lamotrigine, and carbamazepine are used as mood stabilizers. Antipsychotic drugs, antidepressant and tranquilizers are used to control HD [18].

Many non-drug based measures are effective in the management of HD, and these are often more helpful than drugs. The physicians, nurses, physiotherapists, speech and language therapists and other health care workers play a major role on these patients. Though the pharmacological effect is not up to the mark both pharmacological and non-pharmacological treatments are necessary. Because of the limited evidence, their use is based on extensive clinical experience. Physiotherapy is normally done to optimize and strengthen gait and balance, and to assess for walking aids. Occupational therapy can be considered to modify home environment and improve safety and weighted wrist bands to combat limb chorea. Occupational therapy is also advisable to overcome apathy and difficulty in initiating activities. Apart from these appoint experienced healthcare professionals to help at home, residential or nursing home care, day centres to maintain social interactions. Speech and language therapy is practiced optimizing speech and to advise on safest food consistencies at different stages of disease. Develop strategies to deal with cognitive and emotional challenges of disease using counselling or cognitive behavioural therapy. Exercise plays a major role in controlling the disease [25]. Physicians are recommended that patients are referred to a specialist multidisciplinary HD clinic wherever it is possible, so that they can access care from healthcare professionals experienced in the management of the disease. Support from professionals in the community remains vital, and optimal care is typically provided by a multidisciplinary team that includes some or all the following: general practitioners, neurologists, geneticists, psychiatrists, physiotherapists, occupational therapists, speech and language therapists, dietitians, community mental health teams, and social workers. Presently HD advisers are available throughout England and Wales to support patients and their families, and to provide educational input for healthcare professionals caring for people with the disease [26]. As the HD progress the dysphagia occurs. Hence it is recommended that a person with HD and their carers seek professional advice to make sure their diet is nutritious, with lots of calories and easy to eat [27].

Table 3: Therapeutic approaches to Huntington's disease developed by the pharmaceutical companies in current or future multi-site clinical trials

\begin{tabular}{|c|c|c|c|c|c|}
\hline & $\begin{array}{l}\text { Type of } \\
\text { approach }\end{array}$ & Drug/No drug and mode of action & Clinical trial & Hope to society & References \\
\hline UniQure & $\begin{array}{l}\text { Genetic } \\
\text { therapies to } \\
\text { lower huntingtin }\end{array}$ & $\begin{array}{l}\text { AMT-130: It is delivered by a brain } \\
\text { surgery and uses a virus to spread the } \\
\text { treatment throughout the brain. The } \\
\text { treatment targets the genetic messages } \\
\text { of both harmful and normal huntingtin } \\
\text { protein, lowering both. }\end{array}$ & $\begin{array}{l}\text { Phase I/II safety } \\
\text { trial }\end{array}$ & $\begin{array}{l}\text { Experimental data in small, } \\
\text { large animals and three } \\
\text { publications which together } \\
\text { show good safety, stability, } \\
\text { and spread of AMT-130 } \\
\text { throughout the brain. }\end{array}$ & {$[28,29]$} \\
\hline Novartis & A pill to lower & Branaplam: It was developed to treat & Received orphan & Hopefully launched in 2021 & [30] \\
\hline
\end{tabular}

drug status. Used

in a clinical trial to

treat people with

HD.

Atalanta

Therapeutics

New genetic technologies to treat Huntington's disease

Locanabio New genetic technologies to treat HD

Annexon Biosciences Stopping the complement system
RNAi therapies for different neurodegenerative diseases, including Huntington's disease. RNAi therapies work in a similar way to anti-sense oligonucleotides by interfering with a specific genetic message to lower the levels of a specific protein.

Aims to target genetic messages which contain the instructions for cells to make disease causing proteins, such as the harmful form of huntingtin. ANX005: Therapy targets part of the immune system. People with HD seem to have overactive complement systems that leads to nerve cell damage and changes to the connections between brain cells. This therapy aims to stop the complement system from switching on too much.
Phase I clinical

trial in healthy people is currently underway to investigate the safety of PTC518.

Provisional data shared at a recent investor meeting looks more promising and indicates this therapy is working as expected, and no dangerous side effects have been identified yet. Atalanta makes a special form of RNAi which has a branched structure and is able to spread well throughout the brain, so they think this will be good for treating brain related diseases.

More details yet to come and expecting better outcome.

Phase II trial underway for Huntington's patients with their drug

Expecting better outcome. 


\begin{tabular}{|c|c|c|c|c|c|}
\hline & $\begin{array}{l}\text { Type of } \\
\text { approach }\end{array}$ & Drug/No drug and mode of action & Clinical trial & Hope to society & References \\
\hline Prilenia & $\begin{array}{l}\text { Stopping the } \\
\text { complement } \\
\text { system }\end{array}$ & $\begin{array}{l}\text { Pridopidine: Action on sigma } 1 \\
\text { receptor. }\end{array}$ & Phase III trial & Expecting better outcomes. & {$[36,37]$} \\
\hline $\begin{array}{l}\text { Triplet } \\
\text { Therapeutics }\end{array}$ & $\begin{array}{l}\text { Stopping CAG } \\
\text { repeat } \\
\text { expansion }\end{array}$ & $\begin{array}{l}\text { TTX-3360: Targeting DNA damage } \\
\text { repair processes, with the aim of } \\
\text { slowing or halting the progression of } \\
\text { HD. Aims to track HD progression over } \\
\text { time and further explore CAG repeat } \\
\text { expansion along with the development } \\
\text { of symptoms. The main goal is to } \\
\text { determine the best time to treat. }\end{array}$ & - & Expecting better outcome. & [38] \\
\hline $\begin{array}{l}\text { LoQus23 } \\
\text { Therapeutics }\end{array}$ & $\begin{array}{l}\text { Stopping CAG } \\
\text { repeat } \\
\text { expansion }\end{array}$ & $\begin{array}{l}\text { Targeting DNA damage repair } \\
\text { processes, with the aim of slowing or } \\
\text { halting the progression of HD }\end{array}$ & & Expecting better outcome. & {$[11,38]$} \\
\hline $\begin{array}{l}\text { Sage } \\
\text { Therapeutics }\end{array}$ & $\begin{array}{l}\text { Targeting the } \\
\text { symptoms of } \\
\text { Huntington's } \\
\text { disease }\end{array}$ & $\begin{array}{l}\text { SAGE-718: developing and validating } \\
\text { patient-reported outcome and it } \\
\text { involves questions answered directly } \\
\text { by patients, rather than measurements } \\
\text { made by doctors. }\end{array}$ & $\begin{array}{l}\text { Phase I/II clinical } \\
\text { trial }\end{array}$ & Expecting better outcome. & [39] \\
\hline $\begin{array}{l}\text { Neurocrine } \\
\text { Biosciences }\end{array}$ & $\begin{array}{l}\text { Targeting the } \\
\text { symptoms of } \\
\text { Huntington's } \\
\text { disease }\end{array}$ & $\begin{array}{l}\text { Valbenazine: similar to treatments like } \\
\text { tetrabenazine and deutetrabenazine } \\
\text { and has already been approved for a } \\
\text { disorder called tardive dyskinesia. }\end{array}$ & $\begin{array}{l}\text { Phase III clinical } \\
\text { trial. KINECT-HD- } \\
\text { study } \\
\text { valbenazine's } \\
\text { effects on the } \\
\text { movement } \\
\text { symptoms of HD } \\
\text { (chorea) }\end{array}$ & Expecting better outcome. & {$[28,40,41]$} \\
\hline
\end{tabular}

\section{Observational and local studies}

For understanding HD and identifying new aspects of HD biology to focus on for future drug development observational studies are also in progress. ENROLL-HD is an observational study for HD families that monitors how HD appears and changes in people over time [42]. Through a better understanding of HD, scientists hope they might learn how to make better medicines for HD. Clarity is a cerebrospinal fluid collection initiative to facilitate therapeutic development for $\operatorname{HD}[43,44]$. Researchers use the exact same methods to collect spinal fluid from participants all over the world, and these samples provide a window into how the nervous system is affected by HD. At present academic groups are also conducting research [PREDICT-HD] on a smaller scale population by collecting family survey and questionnaires, observing communication style and advising genetic testing to improve the quality of life by doing physical therapy and speech pathology regimens, or testing existing drug combinations or alternative therapies to improve side effects or sleep $[45,46]$.

\section{CONCLUSION}

The rare and family disease (HD) has no cure as far now, but treatments can be given through both pharmacological and nonpharmacological methods. Many organisations are there globally, and the clinical trials are on process. To perform the efficacy and safety of the drug right dose is required. More emphasis should be laid on clinical trials of this disease so that more efficient treatments of the disease could be done. Gene therapy can be optimistic. The screening of the embryo for the test tube baby must be enhanced in order to stop the family mutations (disease). It is perpetuity in family, to break this cloud that threatens the family in effort to bring them hope and optimism by doing this together with them as they volunteer to participate in trials it can be useful, though the outcomes are not known. There must be hope in patients, now it's much more than expectations. Expectations lead to disappointment but with hope they can survive. Sharing their sorrow and disappointment can give them hope. The present review would be beneficial for the researchers working in the field of development of new drugs for the treatment of HD and to look forward for more effective strategies to eradicate this difficulty completely. In next 20 $\mathrm{y}$ we see that this disease will be cured at the initial stages, within days they are born.

\section{ACKNOWLEDGMENT}

The authors would like to thank Dr A Suganthi, Associate Professor from College of Pharmacy, Sri Ramakrishna Institute of Paramedical Sciences, Coimbatore for her valuable suggestions and encouragement during the data collections for the review.

\section{FUNDING}

Nil

\section{AUTHORS CONTRIBUTIONS}

All the authors have contributed equally.

\section{CONFLICT OF INTERESTS}

Declared none

\section{REFERENCES}

1. Novak MJU, Tabrizi SJ. Huntington's disease. BMJ. 2010;340(jun30 4):c3109. doi: 10.1136/bmj.c3109.

2. Machiela E, Southwell AL. Biological aging and the cellular pathogenesis of Huntington's disease. J Huntingtons Dis. 2020;9(2):115-28. doi: 10.3233/JHD-200395, PMID 32417788.

3. Charles J, Lessey L, Rooney J, Prokop I, Yearwood K, Da Breo H, Rooney P, Walker RH, Sobering AK. Presentation and care of a family with Huntington disease in a resource-limited community. J Clin Mov Disord. 2017;4:4. doi: 10.1186/s40734017-0050-6. PMID 28413688.

4. Myers RH. Huntington's disease genetics. Neurotherapeutics. 2004;1(2):255-62. doi: 10.1602/neurorx.1.2.255.

5. Caron NS, Wright GEB, Hayden MR, Adam MP, Ardinger HH, Pagon RA. Huntington disease. In: Seattle: University of Washington. Seattle; 2020. p. 1993-2021. Available from: https://www.ncbi.nlm.nih.gov/books/NBK1305/. [Last accessed on 20 Jul 2021]

6. Nopoulos PC. Huntington disease: a single-gene degenerative disorder of the striatum. Dialogues Clin Neurosci. 2016;18(1):91-8. doi: 10.31887/DCNS.2016.18.1/pnopoulos, PMID 27069383.

7. Roos RA. Huntington's disease: a clinical review. Orphanet J Rare Dis. 2010;5:40. doi: 10.1186/1750-1172-5-40, PMID 21171977. 
8. Saranya S, Sharon KJ, Arya MA, Sachin T, Amrutha VU, Arya GK. An updated review on the application of dendrimers as successful nanocarriers for brain delivery of therapeutic moieties. Int J Appl Pharm. 2021;13:1-9.

9. Ajitkumar A, De Jesus O. Huntington disease. StatPearls: 2021. Available from: https://www.ncbi.nlm.nih.gov/ books/NBK559166. [Last accessed on 20 Jul 2021]

10. Huntington disease: MedlinePlus Genetics. Available from: https://medlineplus/.gov/genetics/condition/Huntingtondisease. [Last accessed on 30 Jul 2021]

11. Wild EJ, Tabrizi SJ. Therapies targeting DNA and RNA in Huntington's disease. Lancet Neurol. 2017;16(10):837-47. doi: 10.1016/S1474-4422(17)30280-6, PMID 28920889.

12. Huntington G. On chorea george Huntington. J Neuropsychiatry Clin Neurosci. 2003;15(1):109-12. doi: 10.1176/jnp.15.1.109, PMID 12556582.

13. Raymond LA, Andre VM, Cepeda C, Gladding CM, Milnerwood AJ, Levine MS. Pathophysiology of huntington's disease: timedependent alterations in synaptic and receptor function. Neuroscience. 2011;198:252-73. doi: 10.1016/ j.neuroscience.2011.08.052, PMID 21907762.

14. Krishnendu PR, Arjun B, Vibina K, Nivea CTS, Drisya NK, Radhika M. Review on evaluating the role of NSAIDs for the treatment of Alzheimer's disease. Int J Appl Pharm. 2021;13(1):91-4.

15. Paulsen JS. Cognitive impairment in Huntington disease: diagnosis and treatment. Curr Neurol Neurosci Rep. 2011;11(5):474-83. doi: 10.1007/s11910-011-0215-x, PMID 21861097.

16. Paoli RA, Botturi A, Ciammola A, Silani V, Prunas C, Lucchiari C, Zugno E, Caletti E. Neuropsychiatric burden in Huntington's disease. Brain Sci. 2017;7(6):67. doi: 10.3390/ brainsci7060067, PMID 28621715.

17. Nambron R, Silajdzic E, Kalliolia E, Ottolenghi C, Hindmarsh P, Hill NR, Costelloe SJ, Martin NG, Positano V, Watt HC, Frost C, Bjorkqvist M, Warner TT. A metabolic study of Huntington's disease. PLOS One. 2016;11(1):e0146480. doi: 10.1371/journal.pone.0146480, PMID 26744893.

18. Schiefer J, Werner CJ, Reetz K. Clinical diagnosis and management in early Huntington's disease: a review. Degener Neurol Neuromuscul Dis. 2015;5:37-50. doi: 10.2147/DNND.S49135, PMID 32669911.

19. Mestre TA, Forjaz MJ, Mahlknecht P, Cardoso F, Ferreira JJ, Reilmann R, Sampaio C, Goetz CG, Cubo E, Martinez Martin P, Stebbins GT. Members of the movement disorder society committee on rating scales development. Rating scales for motor symptoms and signs in Huntington's disease: critique and recommendations. Mov Disord Clin Pract. 2018;5(2):111-7. doi: 10.1002/mdc3.12571, PMID 30363393.

20. Chokhawala K, Stevens L. Antipsychotic medications in StatPearls. Treasure Island, (FL): StatPearls Publishing; 2021. Available from: http://www.ncbi.nlm.nih.gov/ books/NBK519503. [Last accessed on 27 Jul 2021].

21. Voysey ZJ, Barker RA, Lazar AS. The treatment of sleep dysfunction in neurodegenerative disorders. Neurotherapeutics. 2021;18(1):202-16. doi: 10.1007/s13311020-00959-7, PMID 33179197.

22. Shih HI, Lin CC, Tu YF, Chang CM, Hsu HC, Chi CH, Kao CH. An increased risk of reversible dementia may occur after zolpidem derivative use in the elderly population: a population-based case-control study. Med (Baltim). 2015;94(17):e809. doi: 10.1097/MD.0000000000000809, PMID 25929937.

23. Chiu CT, Wang Z, Hunsberger JG, Chuang DM. Therapeutic potential of mood stabilizers lithium and valproic acid: beyond bipolar disorder. Pharmacol Rev. 2013;65(1):105-42. doi: 10.1124/pr.111.005512, PMID 23300133.

24. Song H, Li H, Guo S, Pan Y, Fu Y, Zhou Z, Li Z, Wen X, Sun X, He B, Gu H, Zhao Q, Wang C, An P, Luo S, Hu Y, Xie X, Lu B. Targeting Gpr52 lowers mutant HTT levels and rescues Huntington's disease-associated phenotypes. Brain. 2018;141(6):1782-98. doi: 10.1093/brain/awy081, PMID 29608652.

25. Frank S. Treatment of Huntington's disease. Neurotherapeutics. 2014;11(1):153-60. doi: 10.1007/s13311-013-0244-z, PMID 24366610 .
26. McColgan P, Tabrizi SJ. Huntington's disease: a clinical review. Eur J Neurol. 2018;25(1):24-34. doi: 10.1111/ene.13413, PMID 28817209.

27. Christodoulou CC, Demetriou CA, Zamba-Papanicolaou E. Dietary intake, Mediterranean diet adherence and caloric intake in Huntington's disease: a review. Nutrients. 2020;12(10):e2946. doi: 10.3390/nu12102946, PMID 32992896.

28. Rodrigues FB, Wild EJ. Huntington's disease clinical trials corner: April 2020. J Huntingtons Dis. 2020;9(2):185-97. doi: 10.3233/JHD-200002, PMID 32250312.

29. Leavitt BR, Kordasiewicz HB, Schobel SA. Huntingtin-lowering therapies for Huntington disease: a review of the evidence of potential benefits and risks. JAMA Neurol. 2020;77(6):764-72. doi: 10.1001/jamaneurol.2020.0299, PMID 32202594.

30. McKenzie H. Novartis sees glimmer of hope for Branaplam in Huntington's disease. Available from: https://www.biospace.com/article/novartis-sees-glimmer-ofhope-for-branaplam-in-huntington-s-disease. [Last accessed on 20 Oct 2020]

31. Marxreiter F, Stemick J, Kohl Z. Huntingtin lowering strategies. Int J Mol Sci. 2020;21(6):2146. doi: 10.3390/ijms21062146, PMID 32245050.

32. Harding R. Huntington's disease clinical trial round up. In: Dr Fox L, editor. Available from: https://en.hdbuzz.net/303. [Last accessed on 15 Jun 2021]

33. La Spada AR. A novel therapy for huntington's disease. Cerebrum. 2018;2018:11-8. PMID 30746028.

34. Carpanini SM, Torvell M, Morgan BP. Therapeutic inhibition of the complement system in diseases of the central nervous system. Front Immunol. 2019;10:362. doi: 10.3389/fimmu.2019.00362, PMID 30886620.

35. Sanjay CK. Phase 2a study of ANX005, a humanized anti-C1q $\mathrm{mAb}$, in patients with huntington disease, Huntington study group annual conference. Clinical Trial Round-up Session; 2020. Availablefrom: https://annexonbio.com/documents/HS G-ANX005-Clinical-Trial-Round-up-2020_10_08.pdf.

36. Grachev ID, Meyer PM, Becker GA, Bronzel M, Marsteller D, Pastino G, Voges O, Rabinovich L, Knebel H, Zientek F, Rullmann M, Sattler B, Patt M, Gerhards T, Strauss M, Kluge A, Brust P, Savola JM, Gordon MF, Geva M, Hesse S, Barthel H, Hayden MR, Sabri O. Sigma-1 and dopamine D2/D3 receptor occupancy of pridopidine in healthy volunteers and patients with Huntington disease: a $[18 \mathrm{~F}]$ fluspidine and [18F] fallypride PET study. Eur J Nucl Med Mol Imaging. 2021;48(4):1103-15. doi: 10.1007/s00259-020-05030-3, PMID 32995944.

37. Ryskamp D, Wu J, Geva M, Kusko R, Grossman I, Hayden M, Bezprozvanny I. The sigma-1 receptor mediates the beneficial effects of pridopidine in a mouse model of Huntington disease. Neurobiol Dis. 2017;97(A):46-59. doi: 10.1016/j.nbd. 2016.10.006, PMID 27818324.

38. Robert S, Lahue RS. New developments in Huntington's disease and other triplet repeat diseases: DNA repair turns to the dark side. Neuronal Signal. 2020;4(4):NS20200010:NS20200010. doi: 10.1042/NS20200010, PMID 33224521.

39. Rodrigues FB, Ferreira JJ, Wild EJ. Huntington's disease clinical trials corner: June 2019. J Huntingtons Dis. 2019;8(3):363-71. doi: 10.3233/JHD-199003, PMID 31381524.

40. Uhlyar S, Rey JA. Valbenazine (Ingrezza): the first FDAapproved treatment for tardive dyskinesia. $\mathrm{P} T$. 2018;43(6):328-31. PMID 29896031.

41. Efficacy, safety, and tolerability of valbenazine for the treatment of chorea associated with Huntington disease (KINECT-HD). Available from: https://clinicaltrials.gov/ct2/show/NCT04102579. [Last accessed on 17 Jul 2021].

42. Landwehrmeyer GB, Fitzer Attas CJ, Giuliano JD, Gonçalves N, Anderson KE, Cardoso F, Ferreira JJ, Mestre TA, Stout JC, Sampaio C. Data analytics from enroll-HD, a global clinical research platform for Huntington"s disease. Mov Disord Clin Pract. 20162017;4(2):212-24. doi: 10.1002/mdc3.12388, PMID 30363395. 
43. Wild EJ. Huntington"s disease: the most curable incurable brain disorder? Biomedicine. 2016;8:3-4. doi: 10.1016/ j.ebiom. 2016.05.023, PMID 27428401.

44. Wild E. HDClarity: a multi-site cerebrospinal fluid collection initiative to facilitate therapeutic development for Huntington's disease (HDClarity). Available from: https://clinicaltrials.gov/ ct2/show/NCT02855476. [Last accessed on 02 Jul 2021]
45. Sampaio C, Borowsky B, Reilmann R. Clinical trials in Huntington"s disease: Iinterventions in early clinical development and newer methodological approaches. Mov Disord. 2014;29(11):1419-28. doi: 10.1002/mds.26021, PMID 25216371.

46. Paulsen JS. Neurobiological predictors of Huntington's disease (PREDICT-HD) (PREDICT-HD). Available from: https://clinicaltrials.gov/ct2/show/NCT00051324. [Last accessed on 16 Jun 2021]. 